\title{
Analysis of the Chemical Properties of Vertisols in Kerau, Guyuk Area of Adamawa State, Nigeria
}

\author{
Jinga C. Jahknwa ${ }^{1}$, Helen H. Ray ${ }^{2}$ \\ ${ }^{I}$ (Department of Geography and Disaster Management, Adamawa State Polytechnic, Yola, Nigeria) \\ ${ }_{2}^{2}$ (Department of Geography, ModibboAdama University of Technology, Yola, Nigeria)
}

\begin{abstract}
This study analyzed some chemical properties of vertisol of Kerau in Guyuk area of Adamawa State, Nigeria. The study examined the chemical properties of vertisols and assessed their variability at a small scale. Grid sampling was used to collect 100 soil samples at top soil and subsoil depths of a $2.2 \mathrm{ha}$ farm. Standard analytical methods were used to measure $\mathrm{pH}_{\text {water }}, \mathrm{SOM}, \mathrm{CEC}, \mathrm{PBS}$, Av.P. The coefficient of variability, semivariogram analysis and kriging interpolation were used to assess spatial variation and distribution of soil properties at the study site. The Gaussian and the spherical models provided the best fit for soil properties measured. Most soil properties exhibited moderate to low variability, strong spatial dependence and patch-like distributions. Limiting soil properties at the site are SOM and Av.P. thus the need tailor soil management to take care of this problem.
\end{abstract}

Keywords: Kerau, kriging, semivariograms, variation, vertisols, interpolation

\section{Introduction}

The need for site specific investigation of soil properties is with a view to overcoming problems of soil variability. The inherent variability in soil properties is a function of soil type, scale, nature of landuse and subsisting climatic factors among other things [1][2][3]. Thus, to understand this variability for the adoption of right soil management practices and soil quality monitoring, there is need to know a particular soil's chemical properties variability in terms of the range and pattern on specific base [4]. Soil chemical properties such as $\mathrm{pH}$, CEC, OM, PBS and Available Phosphorus (Av.P) determine to a large extent the productivity of a soil especially from fertility point of view.

Most studies on soil properties variability are on a rather large scale suited for regions where farm holdings span kilometers in range [5][6][7][8]. For example, Nethononda et al [5] assessment of the spatial variability of chemical properties on a 120 ha irrigation field in South Africa found that the properties $(\mathrm{pH}, \mathrm{K}$, $\mathrm{Ca}, \mathrm{Mg}$ and $\mathrm{P}$ ) measured exhibited strong to moderate spatial dependence while kriged maps showed that soil properties were high in the top soil than in the subsoil. Only in few cases do we have studies on a small scale of a few hectares [9][10][11]. Qiu et al [9] studied variation in the properties of a silt loam on a 10ha paddock and found that coefficient of variability of organic matter and Phosphorus where moderate (range of $16 \%$ to 33\%), with both exhibiting strong spatial dependence and the Gaussian model provided the best fit for the semivariograms. Spatial distribution maps of both properties measured also showed that organic matter was low in the southwest and high in the northeast corner of the paddock while Phosphorus was high along the edges of the paddock. However, these studies were not on a vertisol. Moreover, these studies do not consider variability on smaller farms that fall within field scale of a hectare or less, typically found in Nigeria. The fact remains that the shorter the sampling range the less the variation [12][13]14][2][15]. But the effect of this less variation could still be significant on crops of a given site given the prevailing conditions; thus the need to measure the small variations in soil properties distributions.

Other studies cover variability across two or more soil types [5][10][16][17][18] with very few restricted to a homogenous soil type [6][8][19] mostly on a large scale. It is against this backdrop that this study investigated variability in chemical properties of vertisols on half a hectare farm.

\section{Materials And Methods}

\subsection{Study area}

The study site is a $2.2 \mathrm{ha}$ rectangular piece of sorghum farm located on latitude $9^{0} 38.613 \mathrm{~N}-9^{0} 38.595 \mathrm{~N}$ and longitude $11^{0} 54.623 \mathrm{E}-11^{0} 54.571 \mathrm{E}$, an elevation of approximately $200 \mathrm{~m}$ above sea level and a gentle topography (slope difference of $0.011 \%$ in the north-south direction) in Kerau village of Guyuk local government area in Adamawa State. Kerau village has a wet-dry savannah climate with mean annual rainfall of $978 \mathrm{~mm}$. The wet season spans between April and October with average temperatures as high as $35^{\circ} \mathrm{C}$ in March and relative humidity that reaches $70 \%$ in August, the peak of the rainy season [20]. The local environment is almost arid, having been modified by human activities of sorts such that very few scattered trees and grasses now prevail. The vegetation can thus be described as Sudan savannah grassland. The study area is drained by a 
network of seasonal streams radiating from the Lunguda plateau into the Benue River [21]. The soil of the study area can best be described as vertisols of the ustert suborder [22]. The soils have a deep A-C horizon with gilgai morphology because of their ability to crack and mulch between dry and wet seasons [23]. The study site is continuously cropped with sorghum and beans and fertilizer applications done twice with NPK and Urea.

\subsection{Field and Laboratory methods}

Soil samples were collected with an auger at two sampling depths of $0-15 \mathrm{~cm}$ (to represent the root zone) and $15-30 \mathrm{~cm}$ (to represent zone of elluviation) in March 2012. Thus, a total of 50 soil samples were collected at the two depths using a $15 \mathrm{~m}$ grid sampling design by auger (fig. 2). A Garmin GPS was used to identify sampling locations.

Soil samples were air-dried, crushed and sieved through a $2 \mathrm{~mm}$ mesh size sieve. Physical properties measured are Particle size distribution and plant available water capacity. Chemical properties measured are Soil pH, Soil Organic Matter (SOM), Cation Exchange Capacity (CEC), Percentage Base Saturation (PBS) and Available Phosphorus (Av.P). The Soil pH was determined by 1:2 soil to water ratio [24][25]. The CEC was determined by the ammonium acetate method and then PBS given by: PBS = Base (meq/100g)/CEC X 100 [26]. Soil Organic Matter was determined by the dichromate oxidation otherwise called the Walkely-Black method [28]. This was determined by the Olsen-P method using sodium bicarbonate (NaHCO3) as the extractant[27].

\subsection{Statistical analysis}

Statistical analysis was performed using the gamma environmental design software version 9.3 [29]. Other descriptive statistics such as the coefficient of variation was performed using the SPSS package version 9.3 .

Descriptive statistics computed for this study included the mean, standard deviation, maximum and minimum values, skewness and kurtosis and the coefficient of variability.

Geostatistical analysis was performed to bring out the spatial structure of soil properties in the data set and the pattern of distribution at unsampled locations based on the semivariogram and kriging interpolations. The semivariogram is given by: $\gamma *(h)=\frac{1}{2 N(h)} \sum_{i=1}^{N(h)}\left[z\left(x_{i}\right)-Z\left(x_{i}+h\right)\right]^{2}(1)$ (where $(h)=$ semivariance; $N=$ number of pairs; $h=$ lag distance; $x=$ data pair and $i=$ location in space)

Equation (1) was used to estimate the spatial structure of the variation of variables measured [30][31]. Spatial structure is defined by three properties (range, sill and nugget effect) [29][32][33]. The range (A) is the spatial distance beyond which two observations are independent of each other. The sill $\left(\mathrm{C}_{0}+\mathrm{C}\right)$, which is the model asymptote that can never be less than the nugget. The nugget $\left(\mathrm{C}_{0}\right)$ is the discontinuity at the origin arising from sampling and analytical errors and sources of variation below the sampling interval. 


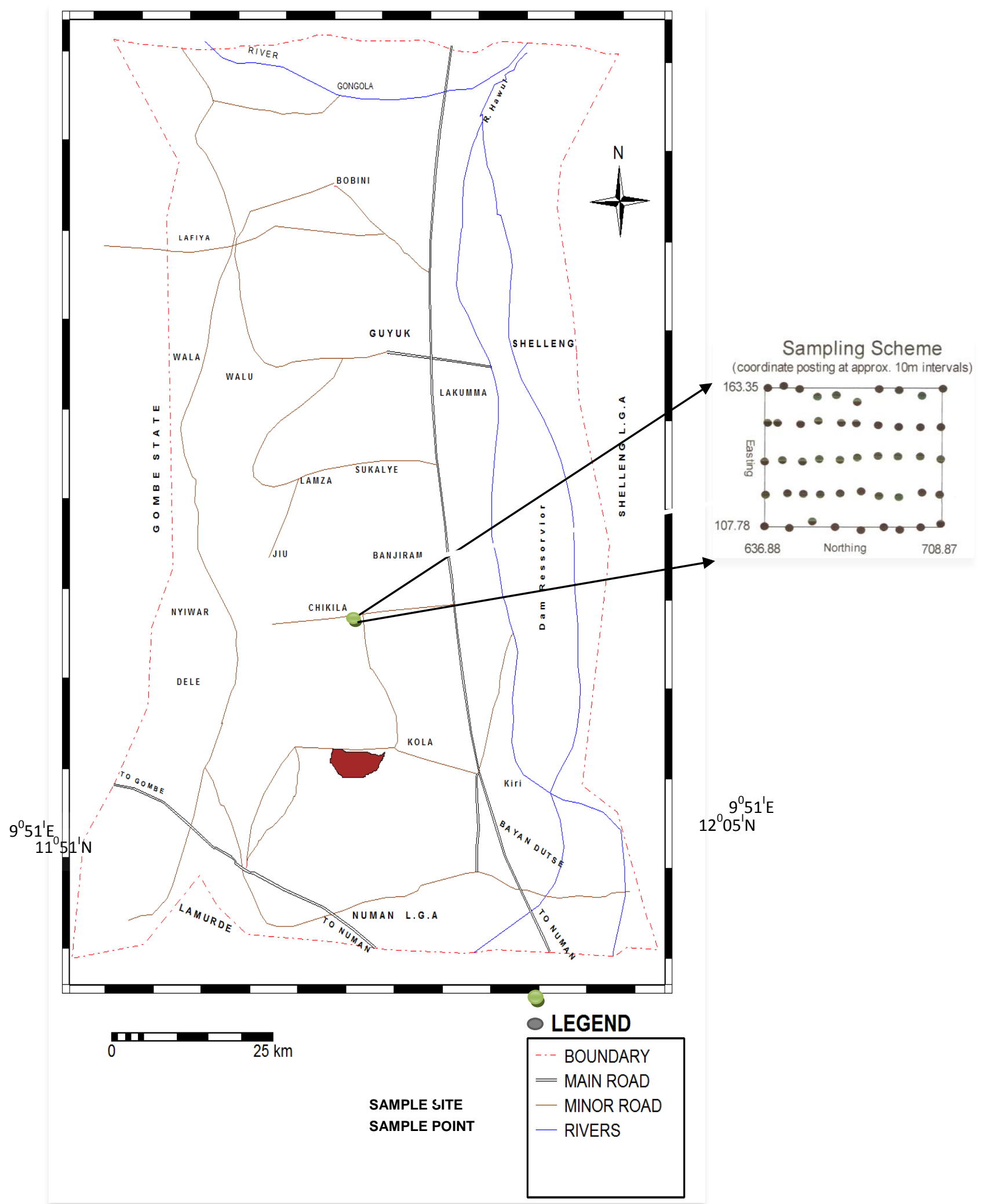

Fig 1.1: MAP OF GUYUK SHOWING KERAU THE STUDY AREA

Source: Ministry of Land and Survey, Yola 


\section{Results And Discussion}

Soil properties analyzed are Soil pH, CEC, PBS, SOM, and Available Phosphorus. Descriptive statistics for chemical properties of the soil at both topsoil depth and subsoil depth as presented in Table 1 shows that Soil pH, CEC and PBS are generally high in Vertisols of the study site. This may be connected with the high Clay content of the soil. Soil properties that exhibited very low values include Soil Organic Matter (SOM), and Available Phosphorus. Low values of SOM indicate depletion of the nutrient at the study site, which may be attributed to continuous intensive tillage/cropping and removal of plant residues for domestic purposes.

The mean values of soil pH, CEC, SOM, and Av. P are slightly higher in the subsoil than in the topsoil; while that of PBS is higher in the topsoil than in the subsoil, suggesting decrease in these soil properties with depth.

The standard deviations for soil $\mathrm{pH}, \mathrm{CEC}, \mathrm{PBS}$ and Av. P are also slightly lower at the top depth than at the subsoil depth. However, only, SOM showed no change at both depths.

Generally, soil properties have small ranges, which are indications of small variation in properties at the study site due probably to the micro-scale nature of the study. Soil $\mathrm{pH}$ ranged from 7.7 to 8.9 at topsoil depth and 7.6 to 9.8 at subsoil depth, an indication of increase with depth and laterally from slight alkalinity to strong alkalinity; CEC ranged from 40 to 47 at topsoil depth and 40 to 53 at subsoil depth (an indication of increasing CEC laterally and with depth); PBS ranged from 88 to 96 at topsoil depth and from 80 to 95 at subsoil depths and; Available P ranged from 3.2 to 9.2 at topsoil depth and 3.9 to 9.4 at subsoil depth, a general indication of low phosphorus content in Vertisols. SOM ranged from 0.08 to 0.26 at surface depth and 0.1 to 0.26 at subsoil depth.

TABLE 1 also shows that with the exception of Av. P and SOM, most of the chemical properties showed higher CV values in the subsoil. However, while Av. P and SOM variability decreases with depth, EC shows no variability with depth. Soil $\mathrm{pH}, \mathrm{CEC}$ and BS exhibited low variability at both topsoil and subsoil depths, while SOM shows high variability. However, only Av. P exhibited moderate variability.

Table 1: Descriptive statistics of soil properties

\begin{tabular}{|c|c|c|c|c|c|c|c|c|c|c|}
\hline Variable & Soil Depth & Mean & SD & SV & Min & Max & Skew & Kurt & $\begin{array}{l}\mathrm{CV} \\
(\%)\end{array}$ & $\begin{array}{l}\text { Variabilit } \\
\mathrm{y}\end{array}$ \\
\hline $\mathrm{Ph}$ & $0-15 \mathrm{~cm}$ & 8.3 & 0.28 & 0.08 & 7.7 & 8.9 & 0.09 & -0.74 & 3 & Low \\
\hline $\mathrm{pH}$ & $15-30 \mathrm{~cm}$ & 8.6 & 0.51 & 0.26 & 7.6 & 9.8 & 0.37 & -0.29 & 6 & Low \\
\hline $\begin{array}{l}\text { CEC } \\
\left(\mathrm{cmol}_{\mathrm{c}} \mathrm{kg}^{-1}\right)\end{array}$ & $0-15 \mathrm{~cm}$ & 42.18 & 2.67 & 7.15 & 37.64 & 48.65 & 0.30 & -0.63 & 6 & Low \\
\hline $\begin{array}{l}\text { CEC } \\
\left(\mathrm{cmol}_{\mathrm{c}} \mathrm{kg}^{-1}\right)\end{array}$ & $15-30 \mathrm{~cm}$ & 48.8 & 3.9 & 14.8 & 40.17 & 55.55 & -0.57 & -0.57 & 8 & Low \\
\hline $\operatorname{PBS}(\%)$ & $0-15 \mathrm{~cm}$ & 92.84 & 2.7 & 7.3 & 87.78 & 96.44 & -0.37 & -1.17 & 3 & Low \\
\hline PBS(\%) & $15-30 \mathrm{~cm}$ & 88.9 & 4.5 & 19.8 & 80.37 & 95.95 & -0.31 & 1.07 & 5 & Low \\
\hline $\operatorname{SOM}(\%)$ & $0-15 \mathrm{~cm}$ & 0.16 & 0.05 & 0.002 & 0.08 & 0.26 & -0.04 & -0.69 & 31 & Moderate \\
\hline $\operatorname{SOM}(\%)$ & $15-30 \mathrm{~cm}$ & 0.17 & 0.05 & 0.002 & 0.1 & 0.26 & -0.26 & -0.88 & 29 & Moderate \\
\hline Av.P(ppm) & $0-15 \mathrm{~cm}$ & 6.55 & 1.4 & 1.9 & 3.2 & 9.2 & -0.44 & -0.47 & 21 & Moderate \\
\hline Av.P(ppm) & $15-30 \mathrm{~cm}$ & 6.8 & 0.9 & 0.8 & 3.9 & 9.4 & -0.23 & -0.32 & 13 & Low \\
\hline
\end{tabular}

Source: (Field Survey, 2012); \%: Percentage; CEC: Cation Exchange Capacity; PBS: Percentage Base Saturation; SOM; Soil Organic Matter; Av.P: Available Phosphorus; kurt: kurtosis [Coefficient of Variability (CV): $\leq 15 \%$ : low; 16-35\%: moderate; >35\%: High variability]

The assessment of spatial structure of soil properties was carried out using semivariogram analysis. A test of normality on each variable was carried out and where necessary appropriate transformations (scale to 110; $\log$ normal; square root) done to ensure a normal distribution. The generation of semivariogram parameters was then carried out for each theoretical model (spherical, exponential, Gaussian and linear). The selection of the best fitting model was based on: the smallest Residual Sums of Squares (RSS), which provides an exact measure of how well the model fits the variogram data (the lower the RSS, the better the model fit); and the biggest (maximum) determination coefficient $\left(\mathrm{r}^{2}\right)$, which also provides an indication of how well the model fits variogram data (should be between 0.5-0.99). Important model parameters are the nugget variance $\left(\mathrm{C}_{0}\right)$ - which is the y-intercept of the model that can never be greater than the sill, the Sill $\left(\mathrm{C}_{0}+\mathrm{C}\right)$ - which is the model asymptote that can never be less than the nugget, the Range (A) - which is the separation distance over which spatial dependence is apparent and the Proportion $\left(C /\left(\mathrm{C}_{0}+\mathrm{C}\right)\right.$ - which provides a measure of the proportion of the sample variance $\left(\mathrm{C}_{0}+\mathrm{C}\right)$ that is explained by the spatially structured variance $(\mathrm{C})$ : it is 1 when the curve passes through the origin (no nugget variance) and 0 where there is no spatially dependent variation at the range specified (pure nugget effect). The results of the semivariogram analysis are presented in table 2 and figs. 1-5. 
Table 2: Semivariogram Analysis of soil properties

\begin{tabular}{|c|c|c|c|c|c|c|c|c|c|}
\hline Variable & $\begin{array}{c}\text { Soil } \\
\text { Depth } \\
(\mathrm{cm})\end{array}$ & Model & $\begin{array}{l}\text { Range } \\
\text { A (m) }\end{array}$ & $\mathrm{r}^{2}$ & RSS & $\mathrm{C}_{\mathrm{o}}$ & $\mathrm{C}_{0}+\mathrm{C}$ & $\frac{C}{\mathrm{Co}+\mathrm{C}}$ & $\begin{array}{r}\frac{C_{o}}{C \mathrm{Co}+\mathrm{C}}(\%) \\
\text { Nugget } \\
\text { to Sill }\end{array}$ \\
\hline $\mathrm{Ph}$ & $0-15$ & Spherical & 30.8 & 0.62 & 0.003 & 0.024 & 0.08 & 0.70 & $30=\mathrm{M}$ \\
\hline $\mathrm{Ph}$ & $15-30$ & Spherical & 18.2 & 0.81 & 0.021 & 0.012 & 0.29 & 0.96 & $4=S$ \\
\hline $\mathrm{CEC}_{\text {(cmolck }}$ & $0-15$ & Gaussian & 15.81 & 0.76 & $4.3 \mathrm{E}-04$ & 0.0001 & 0.046 & 0.99 & $0.22=S$ \\
\hline $\mathrm{CEC}_{\text {(cmolck }}$ & $15-30$ & Gaussian & 16.04 & 0.82 & $1.1 \mathrm{E}-03$ & 0.0001 & 0.081 & 0.99 & $1.23=S$ \\
\hline $\mathrm{PBS}_{(\%)}$ & $0-15$ & Spherical & 24.6 & 0.69 & $2.7 \mathrm{E}-05$ & 0.012 & 0.024 & 0.50 & $50=\mathrm{M}$ \\
\hline $\mathrm{PBS}_{(\%)}$ & $15-30$ & Gaussian & 15.9 & 0.78 & 0.0001 & 0.00 & 0.07 & 0.99 & $0=\mathrm{S}$ \\
\hline $\operatorname{SOM}_{(\%)}$ & $0-15$ & Gaussian & 14.1 & 0.76 & 0.00003 & 0.00 & 0.005 & 0.99 & $0=\mathrm{S}$ \\
\hline $\operatorname{SOM}_{(\%)}$ & $15-30$ & Spherical & 26.82 & 0.8 & 0.0008 & 0.012 & 0.069 & 0.83 & $17.4=S$ \\
\hline Av.P $P_{(\mathrm{ppm})}$ & $0-15$ & Spherical & 18.8 & 0.53 & 2.85 & 0.34 & 2.02 & 0.83 & $17=\mathrm{S}$ \\
\hline Av.P $(\mathrm{ppm})$ & $15-30$ & Spherical & 15.22 & 0.64 & 0.0002 & 0.001 & 0.017 & 0.99 & $6=S$ \\
\hline
\end{tabular}

Source: (Field Survey, 2012); CEC: Cation Exchange Capacity; BS: Base Saturation; OC: Organic Carbon; SOM: Soil Organic Matter; Av. P: Available Phosphorus. $\mathrm{C} / \mathrm{C}_{0}+\mathrm{C}=1$ (no nugget variance) or 0 (pure nugget); Nugget/Sill ratio: $\mathrm{S}=$ Strong $(<25 \%)$; $\mathrm{M}=$ Moderate $(>25 \&<75 \%) ; \mathrm{W}=\mathrm{Weak}(>75 \%)$.

Semivariogram analysis presented in TABLE 2 shows that the Spherical and the Gaussian models adequately described the spatial dependence of the properties of vertisols in the study area. The low RSS and $\mathrm{r}^{2}$ values (above 0.5 ) substantiate the adequacy of these models.

The range of spatial dependence at the topsoil depth varied from $14.1 \mathrm{~m}(\mathrm{SOM})$ to $30.8 \mathrm{~m}(\mathrm{pH})$; while at the subsoil depth it ranged from $15.22 \mathrm{~m}$ for Av.P to $26.82 \mathrm{~m}$ for SOM. The range for each of the soil properties suggests distances beyond which spatial dependence ceases. Thus, future sampling plans must be within the range identified for each soil property in the study area. Observed values of nuggets $\left(\mathrm{C}_{0}\right)$ (in the range of 0.00 to 0.34) suggest the absence or insignificance of nugget effect (random variations) in the semivariogram of soil properties. Very low nugget to sill ratios suggest that all soil properties exhibited strong spatial dependence except for topsoil $\mathrm{pH}$ and PBS that exhibited moderate spatial dependence in the topsoil.

\subsubsection{Soil pH}

Figs 1(a) and (b) shows that the spherical model was the best fit for $\mathrm{pH}$ (with $\mathrm{r}^{2}$ values at 0.62 and 0.81 ) for the two depths. This suggests that there is a gradual decrease in spatial autocorrelation of $\mathrm{pH}$ at both depths within the observed range. The spatial dependence of surface $\mathrm{pH}$ with distance is thus limited to the $30.8 \mathrm{~m}$ range, beyond which there is no spatial autocorrelation. Similarly, the spatial dependence of subsurface $\mathrm{pH}$ with distance is limited to the $18 \mathrm{~m}$ range, an indication of high variability with depth. Soil $\mathrm{pH}$ also exhibited nugget effects laterally and vertically; with smaller value vertically than laterally. This is an indication of the occurrence of random variation laterally than vertically. With a nugget to sill ratio between $30 \%$ laterally and $4.14 \%$ vertically, soil $\mathrm{pH}$ showed a strong spatial correlation structure in both directions (Table 2 above). Soil $\mathrm{pH}$ did not however, show any significant directional variation (anisotropic behavior) in vertisols of the study area at the scale measured. This result agrees with the findings of Yang et al [12] who showed that soil heterogeneity and spatial dependence of $\mathrm{pH}$ at microscale exist and vary with sampling site and scale, while Khan et al [13] and Ayoubi [14] $\mathrm{pH}$ reported low variations in $\mathrm{pH}$ in a field under uniform management in the temperate region.

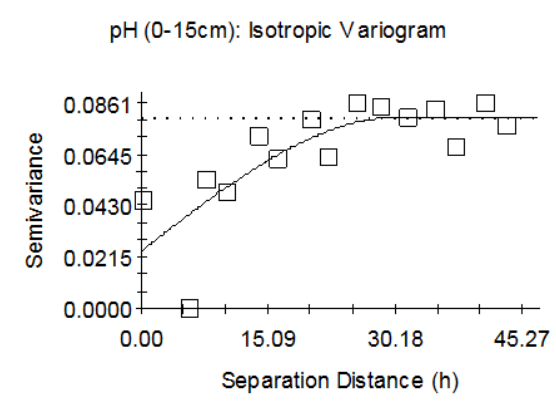

Spherical model $(C o=0.02400 ; C o+C=0.08020 ; A o=30.80 ; \mathbf{r}=\mathbf{0 . 6 2 C}$ RSS $=2.756 \mathrm{E}-03$ )

Fig.1(a): Soil pHVariograms

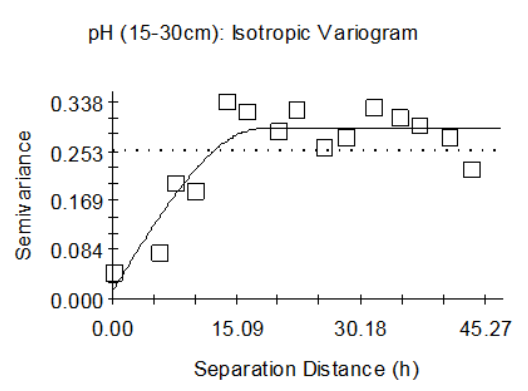

Spherical model $\left(C_{0}=0.01240 ; C_{0}+C=0.29180 ; A o=18.15 ; \mathbf{r} \mathbf{2}=\mathbf{0 . 8 1 1}\right.$ RSS $=0.0209$ )

Fig.1(b): Subsoil pHVariograms 


\subsubsection{Soil Cation Exchange Capacity (CEC)}

Fig. 2 shows that the Gaussian model provided the best fit for CEC both laterally and vertically in KerauVertisols $\left(r^{2}=0.76\right.$ laterally and 0.82 vertically). It also showed that CEC varied at spatial ranges of $16 \mathrm{~m}$ laterally and $9 \mathrm{~m}$ vertically. This is an indication that there is more short range variation in CEC vertically than laterally. A sill to nugget variance ratio of $0.22 \%$ and $0.1 \%$ also indicates a very strong spatial structure in CEC. This result also suggests that variability in CEC of vertisols is caused by structural factors. The mulching ability of vertisols and the mixed cropping system of sorghum and beans at the study site may be the main influence of the resultant short range pattern of variation in the study area.

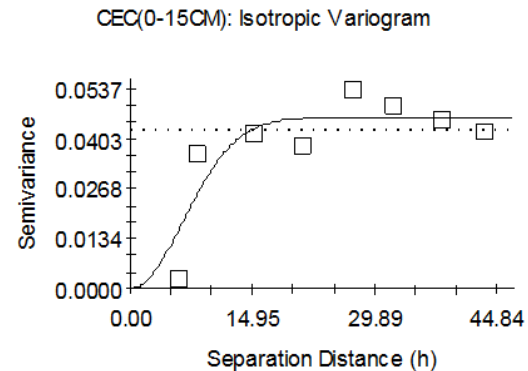

Gaussian model $(C O=0.00010 ; C O+C=0.04600 ; A O=9.13 ; \quad r 2=0.760 ;$ RSS $=4.313 \mathrm{E}-04$ )

Fig.2 (a): Topsoil CEC Variograms

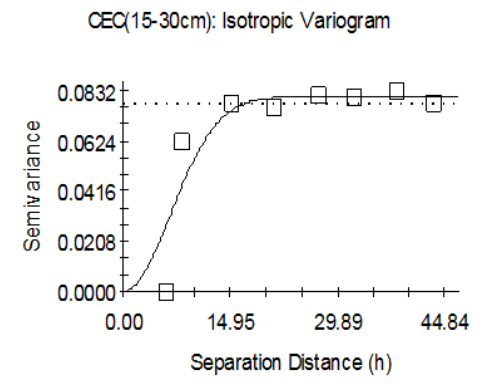

Gaussian model $(C O=0.00010 ; C O+C=0.08070 ; A 0=9.26 ; \mathbf{r}=\mathbf{a . 8 1 6}$ RSS $=1.129 \mathrm{E}-03$

Fig.2 (b): Subsoil CEC Variograms

\subsubsection{Soil Percentage Base Saturation (PBS)}

Fig. 3 shows that the spherical model provided the best fit at the topsoil depth, at a horizontal range of $24 \mathrm{~m}$. This shows that horizontal sampling intervals greater than $24 \mathrm{~m}$ may be inadequate in future sampling plans. Similarly, the Gaussian model provided the best fit for PBS with depth with an $r^{2}$ of 0.78 . The variogram shows a range of $9.2 \mathrm{~m}$ indicating that sampling at a greater depth may not yield any spatial structure. A topsoil nugget to sill ratio of 50\% indicates a moderate spatial dependence laterally. This may be connected with the deep mulching ability of Vertisols. The nugget to sill ratio of $0.1 \%$ also indicates strong spatial dependence with depth. This result shows that PBS variability in vertisols is mainly due to structural or systematic factors.

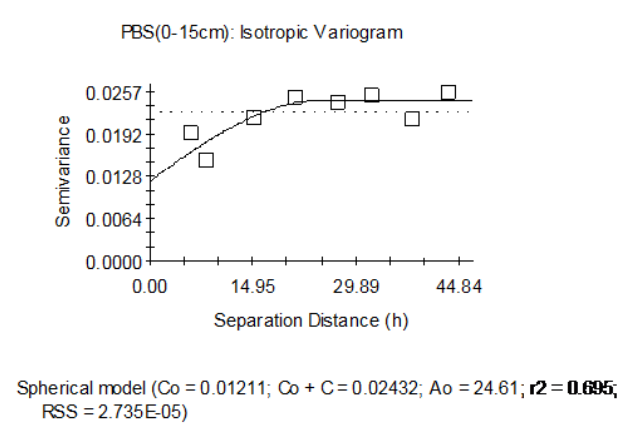

Fig. 3(a): Topsoil PBS Variograms

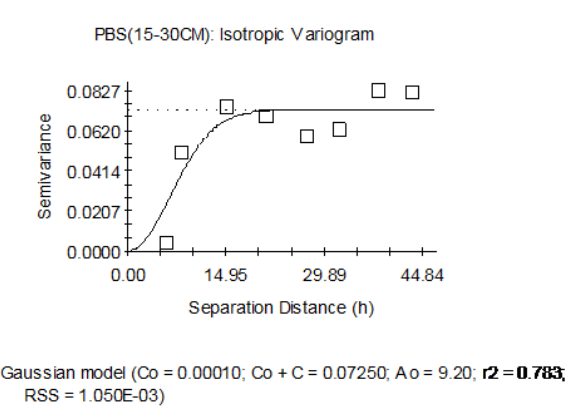

Fig. 3(b): Subsoil PBS Variograms

\subsubsection{Soil Organic Matter (SOM)}

Fig. 4.(a) shows that the Gaussian model provided the best fit for surface SOM indicating smooth and gradual variation towards the observed range ( $\mathrm{r}^{2}$ of 0.65 and 0.91 horizontally and vertically). Thus, SOM is spatially correlated between $7 \mathrm{~m}$ and $10 \mathrm{~m}$ ranges across the field and with depth respectively. This is an indication of short range variation. A nugget to sill ratio of $0.2 \%$ both laterally and with depth suggests strong spatial dependence. The absence of a nugget effect also suggests that variation is more of structural than random, caused more by the continuous nature of cropping of the study site. 


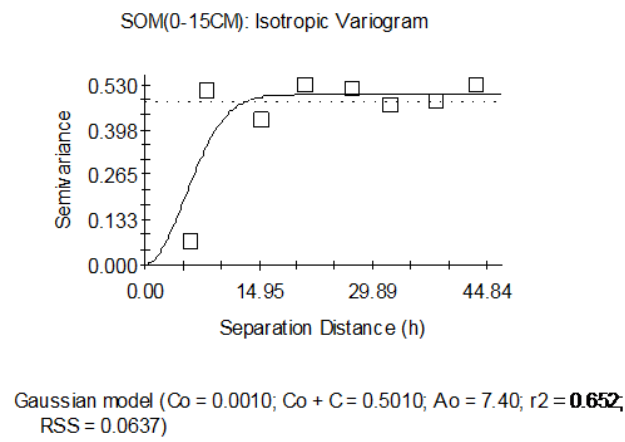

Fig. 4(a):Topsoil SOM Variograms

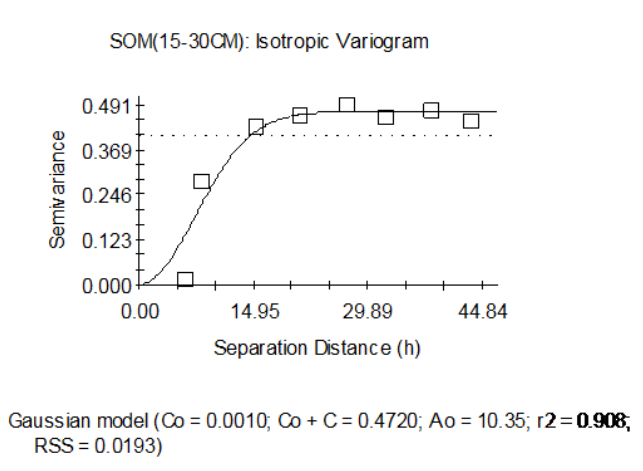

Fig. 4(b):Subsoil SOM Variograms

\subsubsection{Available Phosphorus (Av.P)}

Figs 5(a) and (b) shows that the spherical model best explained the spatial structure of Available phosphorus in Kerauvertisols. The spatial dependence of available phosphorus is in the $18 \mathrm{~m}$ lateral range and $15 \mathrm{~m}$ vertical ranges. With the absence of nugget effect, this short range variation may be due to systematic factors due especially to the mulching ability of Vertisols and other soil conservation practices employed by farmers. In general, nugget to sill ratio of 17 suggests strong spatial structure of available phosphorus in Vertisols. This result is however, contrary to that of Giltrap and Hewitt [34] who reported a spatial dependence of $30 \mathrm{~m}$ laterally and $50 \mathrm{~m}$ range with depth respectively and a nugget to sill ratio between $25 \%$ and $75 \%$ indicating moderate variability. Zhang et al [35], also reported moderate spatial variation structure in available phosphorus. This parity in findings may be attributable to differences in soil type, soil conservation measures in use and other socio-climatic variables.

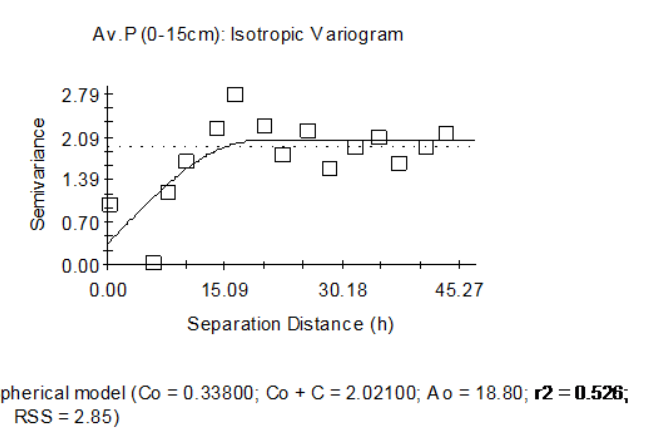

Fig. 5(a): Topsoil Av. PhosphorusVariograms

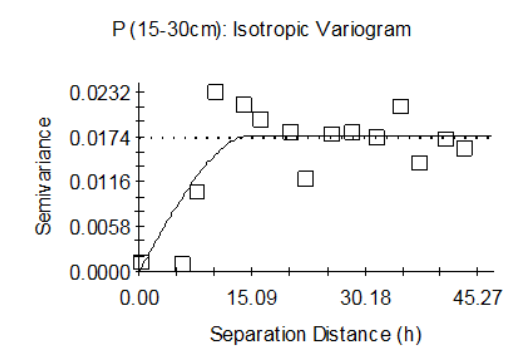

Spherical model $(C o=0.00001 ; C o+C=0.01762 ; A o=15.22 ; \mathbf{r 2}=\mathbf{0 . 6 4 1}$; RSS $=2.313 \mathrm{E}-04$

Fig. 5(b): Subsoil Av. Phosphorus Variograms

\subsection{Spatial Distribution Maps}

The results of semivariogram analysis were used in ordinary kriging interpolation to produce prediction maps of the spatial distribution of soil properties of the study site. The cross validation technique was used to validate the semivariogram models fitted. All the soil properties analysed showed that the experimental models fitted to standard variograms were satisfactory with 16 neighbours as the ideal neighbourhood size for the kriging estimation. The maps are shown in figures 6-11.

\subsubsection{Soil pH Distribution}

Fig. 6(a) shows a patchy distribution of soil $\mathrm{pH}$ at the surface depth with higher values occurring on the western tip and the lower south of the study site. Lower values of $\mathrm{pH}$ occur also at the northern part of the site. Fig. 6(b) also shows a patchy distribution of $\mathrm{pH}$ at the subsurface depth with a patch of high $\mathrm{pH}$ traversing the north-eastern and south-eastern parts of the site interlaced with patches of lower $\mathrm{pH}$ surfaces. This pattern of $\mathrm{pH}$ distribution suggests the localization of nutrient around mounds and depressions associated with the gilgai morphology of vertisols. 


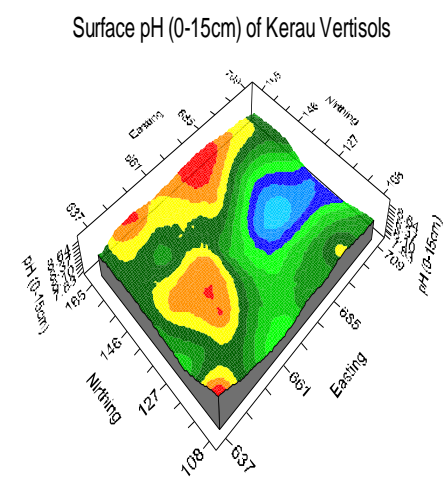

Fig. 6(a): Kriged Maps for Topsoil pH

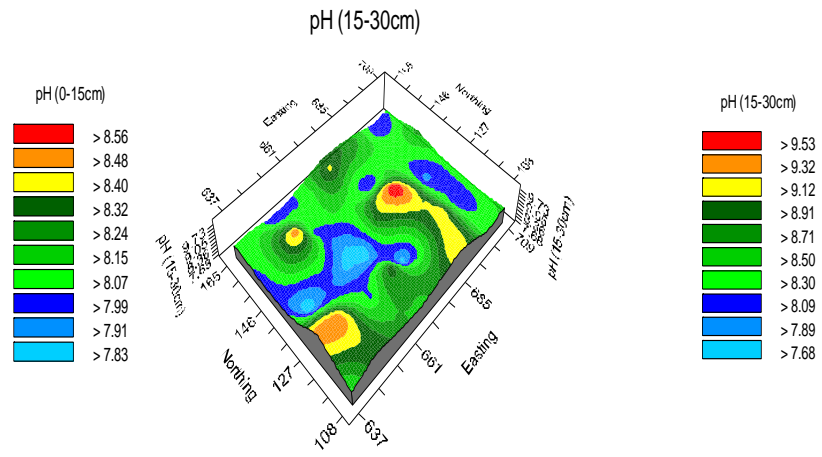

Fig. 6(b): Kriged Maps for Subsoil pH

\subsubsection{Cation Exchange Capacity (CEC) Distribution}

Fig.7(a) shows a patchy occurrence of few hot spots of soil CEC at surface depth (>50 and <40) occurring randomly in the study site. The occurrence of hotspots with higher CEC values may be due to soil conservation inputs such as fertilizer application. There is however a gradational increase in CEC values from $>40$ in the north to $<44$ in the south, in the direction of dip suggesting change in slope pattern as the main cause of this pattern. Fig. 7(b) however, shows high CEC $(\geq 50)$ traversing the middle of site in a northwest to southeast pattern, with lower CEC $(\leq 49)$ decreasing gradually from the center towards the north and south ends of the study site. The spatial distribution pattern of CEC in fig 7 generally shows the higher concentrations in the lower reaches suggesting the influence of slope at the study site.

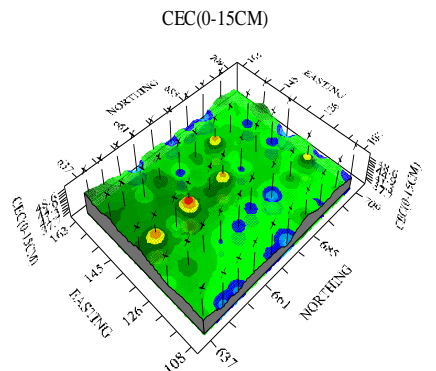

Fig. 7(a): Kriged Maps of Topsoil CEC
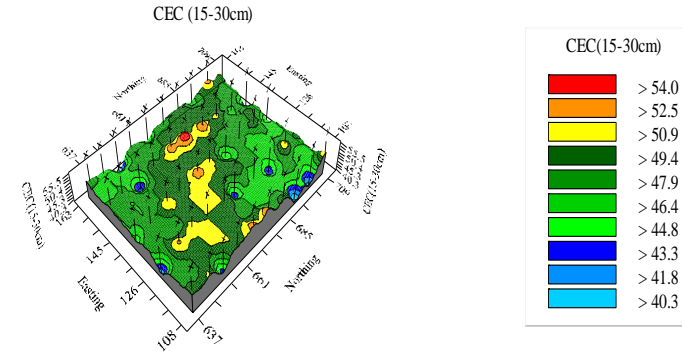

Fig. 7(a): Kriged Maps of Topsoil CEC

\subsubsection{Percentage Base Saturation (PBS) Distribution}

Fig. 8(a) shows that lower values of PBS $(\leq 92)$ occurring in the central part of the study site in a southeast to northwest pattern and increase gradually to high PBS $(\geq 86)$ on the northeast part of the site. Fig. 8(b) also shows a north-south dichotomy in the distribution pattern of subsurface PBS. From the northwest to southeast divide of the study site shows higher PBS values (PBS $\geq 88$ ). Only the southwestern corner of the site has PBS values in the $85 \%$ range.

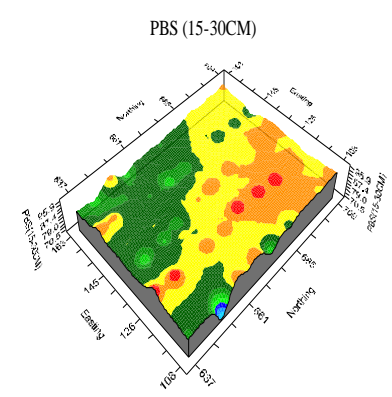

Fig.8(a): Kriged Maps of Topsoil PBS
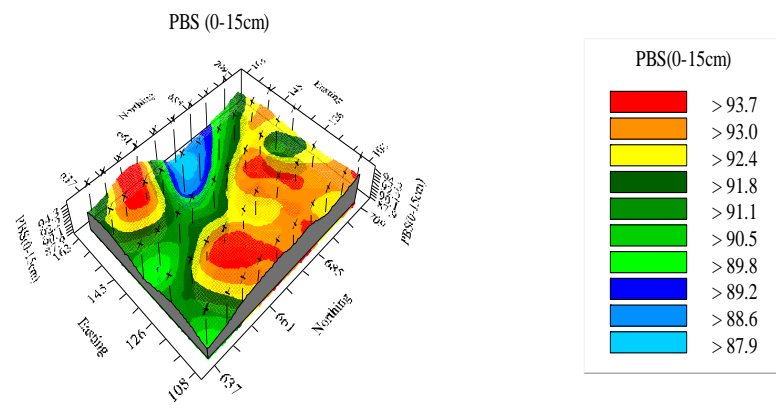

Fig.8(b): Kriged Maps of Subsoil PBS

\subsubsection{Soil Organic Matter (SOM) Distribution}

Fig. 9(a) shows a generally uniform distribution in surface SOM over the entire study site. SOM values between 0.135 and 0.159 are observed to dissect the study site diagonally in a northwest to southeast pattern. Patches of high and low values are also seen to sparingly dot the site. In fig. 9(b), low values of subsurface SOM $(\leq 0.13)$ occupied the eastern part of site while higher SOM $(\geq 0.18)$ occupied the western part of the site. In other 
words, there is a general east-west increase in SOM with high values occupying the northwestern corner of the site. Generally, the study site exhibited very low SOM content. This can be attributed to very short fallow period of about 4 months at the site and the clean clearing done as farm preparation.

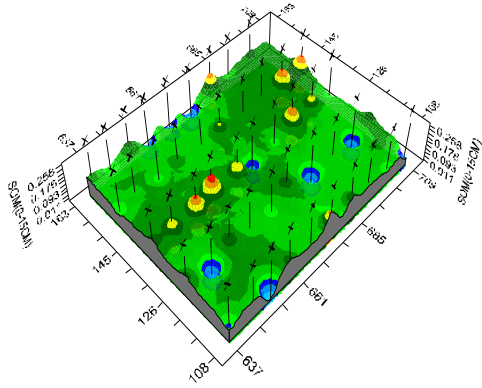

Fig. 9(a): Kriged Maps of Topsoil SOM
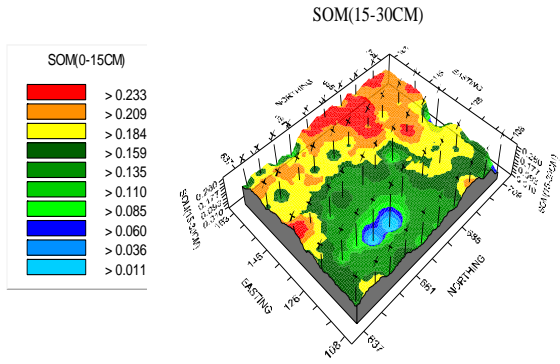

Fig. 9(b): Kriged Maps of Subsoil SOM

\subsubsection{Available Phosphorus (Av. P) Distribution}

Fig. 10(a) also reveals a patchy distribution of high $(\geq 7)$ and low values $(\leq 5.8)$ of Available Phosphorus covering the entire study site. Fig. 10(b) also reveals patchy distribution of Available Phosphorus in the subsurface depth with patches of high Av. P content $(\geq 7)$ found in northeast part of the site. This pattern of nutrient distribution may be attributed to the gilgai morphology associated with vertisols of the study site.

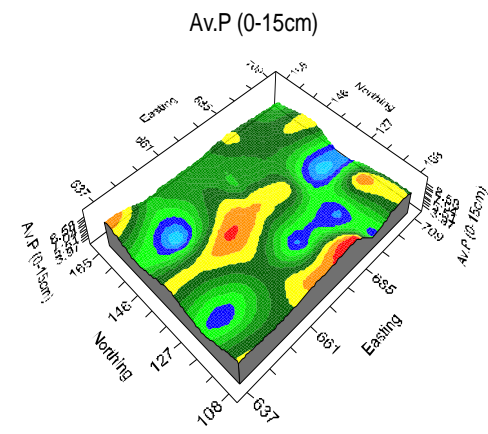

Fig. 10(a): Kriged Maps of Topsoil Av. P
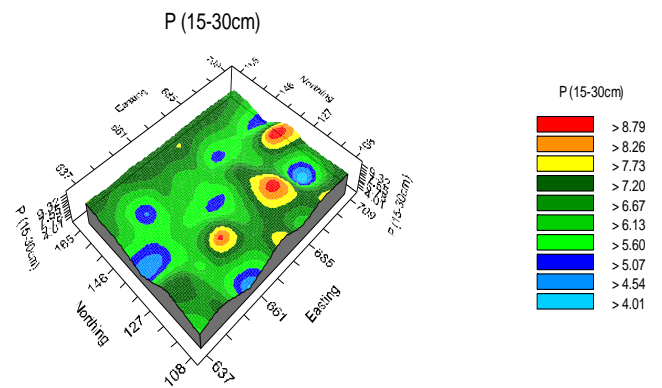

Fig. 10(b): Kriged Maps of Subsoil Av. P

\section{Conclusion}

The findings of these study confirms that spatial variability in soil properties also occurs at a small scale in small farm holdings of less than a hectare with a homogenous soil such as vertisols. Main limiting soil properties in vertisols of the site are SOM, and Av.P. Soil properties variability was either low or moderate. The short range and high spatial dependence may be due to the small scale of measurement used while in general, variation was systematic. Spatial distribution maps revealed no significant relations between the distribution of a property at the surface depth and the subsurface depth. This is perhaps due to the churning ability of vertisols that eliminates the B horizon.

\section{References}

[1]. A. Dobermann, Understanding and managing variability in soils. Lincoln: University of Nebraska, 2010

[2]. RWebster Software review. Eur J Soil Sci 48, 1997, 173-175.

[3]. H. Jenny, Factors of soil formation(New York, N. Y.: McGraw-Hill, 1941).

[4]. B. Bhandari, and R. L. Ficklin,Characterizing the variability of physical and chemical properties across the soil individuals mapped as amy silt loam soils of southeastern Arkansas. Journal of Arkansas Academy of Science, 63, 2009, 15-19

[5]. L. O. Nethononda, J. J. O. Odhiambo and D. G. Paterson, Assessment of spatial variability of selected soil chemical properties in a communal irrigation scheme under resource-poor farming conditions in Vhembe District of Limpopo Province, South Africa. African Journal of Agricultural Research 7(39), 2012, 5438-5445

[6]. S. S. Patil, V. C. Patil and K. A. Al-Gaadi, Spatial variability in fertility status of surface soils. World Applied Sciences Journal, 14(17), 2011, 1020-1024.

[7]. L. A. Gaston, M. A. Locke, R. M. Zablotowicz, and K.N. Reddy, Spatial variability of soil properties and weed populations in the Mississippi delta. Soil Sc. Soc. of Am. Journal, 65, 2001, 449-459.

[8]. S. A. Khresat, and A. Y. Taimeh, Properties and characterization of vertisols developed on limestone in a semi-arid environment. Journal of Arid Environments 40, 1998, 235-244.

[9]. W. Qiu, D. Curtin and M. Beare,Spatial variability of available nutrients and soil carbon under arable cropping in Canterbury. The New Zealand Institute for Plant and Food Research Ltd, 2011 
[10]. A. W. Aisha, S. Zauyah, A. R. Anuar and C. I. Fauziyah, Spatial variability of selected chemical characteristics o paddy soils in Sawah Sempadan, Selangor, Malaysia. Malaysian.Journal of Soil Science 14, 2010, 27-39.

[11]. J . Mohammadi, Spatial variability of soil fertility, wheat yield and weed density in a one hectare field in Shahre Kord. J. Agric. Sci. Technol. 4, 2002, 83-92.

[12]. F. Yang, G. Zhang, X. Yin, and Z. Liu, Field scale spatial variation of saline sodic soil and its relation with environmental factors in western Songmen plain of China. Intl. Journal of Env. Res. and Pub. Health, 8, 2011, 374-387.

[13]. B. T. Khan, Effects of some biological factors on soil variability in the tropics III. Effect on macrotermes mounds. Soil Sci. Soc. Am. J., 50 (1-3), 2007, 241-251.

[14]. S. Ayoubi, O. H. Shalikar, F. Khormali and R. G. Nasrabadi, Responses of soil quality indicators to three crop rotation systems in paddy soils. Iran, 2006.

[15]. C. A. Camberdella, T. B. Moorman, T. B. Parkin, and D. L. Karlen, Field Scale Variability of Soil Properties in Central Iowa. Soil Sci. Soc. Am. J. 58, 1994, 1501-1511

[16]. V. G. D. Nayanaka, W. A. U. Vitharana and R.P. Mapa,Geostatistical analysis of soil properties to support spatial sampling in a paddy growing alfisol. Tropical Agricultural Research 22(1), 2010, 34-44

[17]. Mzuku, M., Khosla, R., Reich, R., Inman, D., Smith, F. and L. McDonald, Spatial variability of measured soil properties across site specific management zones. Soil Sci. Soc. of Am. Journal, 69, 2005, 1572-1579.

[18]. I. A. Jaiyeoba,. Variation of soil chemical properties over Nigerian savanna. Singapore Journal of tropical geography, 16(2), 1995, 141-157.

[19]. W. P. Adderley, D. A. Jenkins, F. L. Sinclair, P. A. Stevens and I. Verinumbe, The influence of soil variability on tree establishment at an experimental agroforestry site inNorth East Nigeria. Soil Use and Management 13, 1997, 1-8

[20]. A. A. Adebayo, Climate II: Rainfall. In A. A. Adebayo, \& A. L. Tukur (Eds.), Adamawa State in Maps, (Yola: Paraclete Publishers, 1999) 23-26.

[21]. A. L. Tukur, Landforms. . In A. A. Adebayo, \& A. L. Tukur (Eds.), Adamawa State in Maps(Yola: Paraclete Publishers, 1999) 1416.

[22]. H. H. Ray, Soils and erosion. In A. A. Adebayo, \& A. Tukur (Eds.), Adamawa State in Maps,(Yola: Paraclete Publishers, 1999) 2731.

[23]. G G.
Sabine,
Vertisols,
(University
of $\quad$ Florida,Retrieved
in
may, 2013)http://soils.ifas.ufl.edu/faculty/grunwald/teaching/eSoilScience/vertisols.shtml

[24]. M. L. Jackson, Soil chemical analysis, (New Delhi: Prentice Hall of India Private Limited, 1973).

[25]. E. O. McLean, Soil pH and lime requirement. In Page, A. L., R. H. Miller and D. R. Keeney (eds.) Methods of soil analysis. Part 2 - Chemical and microbiological properties. (2nd Ed.). Agronomy9, 1982, 199-223.

[26]. C. J. Shollenberger, and F. R. Dreibelbis. Analytical methods in base exchange investigations on soils. Soil Sci. 30 , 1930, $161-173$.

[27]. S. R. Olsen, C. V. Cole, F. S. Watanabe, and L. A. Dean, Estimation of available phosphorus in soils by the extraction with sodium bicarbonate, U.S. Dep. of Agric., Circ. 939, 1954.

[28]. Walkley, A. and C. A. Black, An examination of the Degtjareff method for determining soil organic matter and a proposed modification of the chromic acid titration method. Soil Sci., 37,1934, 29-38.

[29]. G. P. Robertson, GS+. Geostatistics for the Environmental Sciences, Gamma Design Software, (Plainwell, Mich, USA, 2008).

[30]. W. K. Jung, N. R. Kitchen, K. A. Sudduth, and S. H. Handerson, Spatial characteristics of claypan soil properties in an agricultural field. Soil Sci. Soc. Am. J., 70, 2006, 1387-1397.

[31]. E. H. Isaaks, and R. M. Srivastava, An introduction to applied geostatistics.(New York: Oxford University Press 1989).

[32]. P. Goovaerts, Geostatistical tools for characterizing the spatial variability of microbiological and physico-chemical soil properties. Biol. Fertil. Soil,1998, 27, 315-268.

[33]. P. Goovaerts, Geostatistics for natural resources evaluation.(Oxford: Oxford University Press, 1997).

[34]. D.J. Giltrap and A.E. Hewitt, Spatial variability of soil quality indicators in New Zealand. Soil and land uses. New Zealand Journal of Agricultural Research, 47, 2004, 167-177

[35]. Q. Zhang, Z. Yang, Y. Li, D. Chen, J. Zhang, and M. Chen, Spatial variability of soil nutrient management in Yongji county, China. Intl. Journal of Geographical Information Science, 24(7), 2010, 965-968 